\title{
Hvem bør utføre endoskopier?
}

\author{
Om det innføres et nasjonalt screeningprogram for kolorektal kreft, vil behovet for endoskopører øke. Norsk \\ gastroenterologisk forening er svært skeptiske til å la jobbglidning bli løsningen på en slik utfordring.
}

På forespørsel fra Legeforeningen diskuterte Norsk gastroenterologisk forening i 2012 muligheten for at sykepleiere kan utføre endoskopier. Vi konkluderte med at det fra et faglig synspunkt ikke var tilrådelig at gastroenterologisk endoskopi utføres av andre yrkesgrupper enn leger. Muligheten for at sykepleiere skal utføre koloskopier diskuteres på nytt i forbindelse med et forprosjekt for nasjonalt screeningprogram for kolorektal kreft. Dersom det viser seg at det bør innføres screening med sigmoidoskopier eller koloskopi, vil behovet for endoskopører øke. Det er liten tvil om at sykepleiere kan trenes opp til å gjøre endoskopiske undersøkelser, men finnes det gode grunner til at andre enn leger skal endoskopere?

\section{Økonomi og logistikk}

I England og Nederland utfører sykepleiere koloskopier. Til tross for stor lønnsforskjell mellom leger og sykepleiere i disse landene har en studie vist at sykepleierskopier er mindre kostnadseffektive enn legeskopier (1). I Norge er lønnsforskjellen mellom leger og sykepleiere beskjeden i forhold til i disse landene, og man kan derfor tenke seg at sykepleierskopier blir en enda dyrere løsning hos oss. Initiativene til slik oppgaveglidning i Norge må bero på en misforståelse omkring muligheten for en økonomisk besparelse.

I studiene der man har sammenliknet lege- og sykepleierskopier, har nesten alle pasientene fått sedasjon under prosedyren $(2,3)$, slik at samtale med lege uansett måtte foregå før og etter koloskopien. Denne type skopier utføres i Norge i all hovedsak på våkne pasienter. Pasientens spørsmål kan derfor besvares i tilknytning til undersøkelsen, og konsultasjonen avsluttes når koloskopien er ferdig.

\section{Håndtering av komplikasjoner}

Endoskopi er en invasiv undersøkelse med en viss komplikasjonsrate. Komplikasjonene er hovedsakelig knyttet til fjerning av polypper, som kan gi blødninger og tarmperforasjoner (4). Adenomer bør trolig oppdages hos $20-25 \%$ av pasientene som undersøkes i et screeningprogram (5), og det vil tilsvarende ofte bli behov for polyppektomier. Dersom ikke-leger utfører skopier, blir det spørsmål om hvem som skal fjerne polyppene og hvem som har ansvaret ved komplikasjoner. Norsk gastroenterologisk forening mener at dette er ansvarsforhold som ikke kan fordeles på flere yrkesgrupper. Om polyppektomi skal gjøres av lege, innebærer det at en lege må ta over koloskopien av minst hver femte pasient som blir undersøkt i et screeningprogram. En lege må altså være i beredskap for at pasienten skal slippe å vente lenge med skopet $i$ tarmen. Etter at polyppene er fjernet, må histologisvar og videre kontroller også vurderes av lege. Premaligne flate polypper er vanskelige å oppdage, og radikal endoskopisk fjerning er teknisk utfordrende og krever spesialtrente endoskopører for å unngå høy komplikasjonsrate $(6,7)$. Screeningkoloskopi er en utfordrende oppgave, ettersom polypper som overses, behandles inadekvat eller får mangelfull oppfølging, vil kunne få store konsekvenser for pasientene.

\section{Legemangel?}

Det har vært argumentert med at det er legemangel i Norge, slik at andre yrkesgrupper må trenes opp til å gjøre legeoppgaver. Den jobbglidningen som har påvirket legers arbeidskapasitet sterkest de seneste årene, er imidlertid, etter vår mening, overføring av sekretærers arbeid til legene. Det er i dagens situasjon vanskelig å forstå hvorfor klart definerte legeoppgaver skal overtas av andre yrkesgrupper, mens leger bruker en stadig større andel av tiden sin til annet enn pasientrelatert arbeid og mister sekretærer. Kvotesystemet for legestillinger skal snart avvikles, og sykehusene vil da kunne ansette de legene det er behov for (8). De neste årene vil 800-1 000 nye leger utdannes og søke turnusplass i Norge, og det vil ikke bli mangel på unge leger. Leger i spesialisering vil kunne trenes til selvstendige koloskopører i løpet av samme tid som en sykepleier. Man vil da ha utdannet mer fleksibel arbeidskraft, som også kan brukes til andre oppgaver på en gastromedisinsk avdeling.

\section{Flere gastroenterologer}

Medisinskfaglig finner vi ikke ett eneste argument for at koloskopier bør gjøres av andre enn leger. Norsk gastroenterologisk forening er imidlertid enig $i$ at det vil trenges flere endoskopører i fremtiden, særlig dersom det viser seg at pågående studier taler for at nasjonal koloskopiscreening bør startes. Vi oppfordrer helseforetakene til å ansette flere leger i utdanningsstillinger innen gastroenterologi, heller enn å omfordele denne oppgaven til andre yrkesgrupper. Dersom det skal arrangeres møter eller konferanser om jobbglidning generelt, og skopier utført av ikke-leger spesielt, vil foreningen herved melde sin interesse for å delta.

\section{Reidar Fossmark}

reidar.fossmark@ntnu.no

Michael Bretthauer

Bjørn I. Gustafsson
Reidar Fossmark (f. 1971) er dr.med. og overlege ved Avdeling for fordøyelses- og leversykdommer, St. Olavs hospital. Han er leder i Norsk gastroenterologisk forening. Forfatter har fylt ut ICMJE-skjemaet og oppgir ingen interessekonflikter.

Michael Bretthauer (f. 1969) er professor ved Avdeling for helseledelse og helseøkonomi, Universitetet i Oslo, overlege ved seksjon for fordøyelsessykdommer, Avdeling for transplantasjonsmedisin, Oslo universitetssykehus og forskningsveileder ved Sørlandet sjukehus. Forfatter har fylt ut ICMJE-skjemaet og oppgir følgende interessekonflikter: Han har vært rådgiver for Exact Sciences i forbindelse med utarbeiding av ikke-invasiv test for kolorektal kreft. Arbeidsstedet har mottatt utstyr til endoskopistudier fra Olympus, Fujinon, CCS og Falk Pharma.

Bjørn I. Gustafsson (f. 1965) er spesialist i fordøyelsessykdommer ved St. Olavs hospital og professor i gastroenterologi ved Det medisinske fakultet, Norges teknisk-naturvitenskapelige universitet. Han er styremedlem i Norsk gastroenterologisk forening.

Forfatter har fylt ut ICMJE-skjemaet og oppgir ingen interessekonflikter.

\section{Litteratur}

1. Richardson G, Bloor K, Williams J et al. Cost effectiveness of nurse delivered endoscopy: findings from randomised multi-institution nurse endoscopy trial (MINUET). BMJ 2009; 338: b270.

2. Maslekar S, Hughes M, Gardiner A et al. Patient satisfaction with lower gastrointestinal endoscopy: doctors, nurse and nonmedical endoscopists. Colorectal Dis 2010; 12: 1033-8.

3. van Putten PG, Ter Borg F, Adang RP et al. Nurse endoscopists perform colonoscopies according to the international standard and with high patient satisfaction. Endoscopy 2012; 44: 1127-32.

4. Whitlock EP, Lin JS, Liles E et al. Screening for colorectal cancer: a targeted, updated systematic review for the U.S. Preventive Services Task Force. Ann Intern Med 2008; 149: 638-58

5. Kaminski MF, Regula J, Kraszewska E et al. Quality indicators for colonoscopy and the risk of interval cancer. N Engl J Med 2010; 362: 1795-803.

6. Heldwein W, Dollhopf M, Rösch T et al. The Munich Polypectomy Study (MUPS): prospective analysis of complications and risk factors in 4000 colonic snare polypectomies. Endoscopy 2005; 37 : 1116-22.

7. Pohl H, Srivastava A, Bensen SP et al. Incomplete polyp resection during colonoscopy-results of the complete adenoma resection (CARE) study. Gastroenterology 2013; 144: 74-80.e1.

8. Gjessing H. Legefordelingssystemet avvikles. Tidsskr Nor Legeforen 2013; 133: 719.

Mottatt 2.5. 2013 og godkjent 14.5. 2013. Medisinsk redaktør Hanne Støre Valeur.

Publisert først på nett. 